Supporting Information for the paper:

\title{
Investigating the Specific Interactions between Carbonic Anhydrase and a Sulfonamide Inhibitor by Single Molecule Force Spectroscopy
}

\author{
Sarah Kamper, ${ }^{\dagger}$ Laura Porter-Peden, ${ }^{\dagger}$ Ronald Blankespoor, ${ }^{\dagger}$ Kumar Sinniah, ${ }^{*}$ Dejian Zhou, $^{\dagger}$ Chris \\ Abell, ${ }^{\S}$ and Trevor Rayment ${ }^{* *}$ \\ Department of Chemistry \& Biochemistry, Calvin College, Grand Rapids, MI 49546, School of Chemistry, \\ University of Leeds, Leeds, LS2 9JT, UK, Department of Chemistry, University of Cambridge, Lensfield Road, \\ Cambridge CB2 1EW UK, and Department of Chemistry, University of Birmingham, Edgbaston, Birmingham, B15 \\ $2 T T, U K$
}

$\dagger$ Calvin College

University of Leeds

$\S$ University of Cambridge

** University of Birmingham 


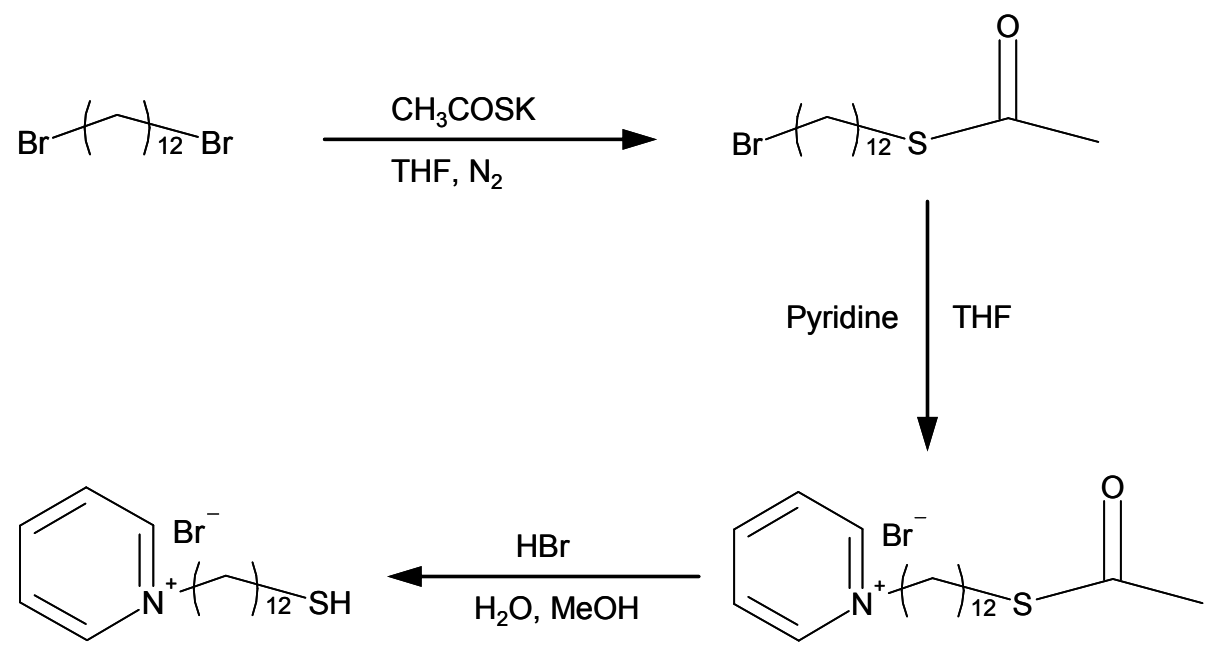

Scheme S1. Procedure for synthesis of N-(12-mercaptododecyl) pyridinium bromide from 1,12-dibromododecane.

Synthesis of 12-bromododecyl thiol acetate. To a solution of $2.77 \mathrm{~g}$ ( $24.3 \mathrm{mmol})$ of potassium thioacetate in $90 \mathrm{ml}$ of THF was added $15.9 \mathrm{~g}(48.5 \mathrm{mmol})$ of 1,12-dibromododecane. The mixture was heated to reflux for 24 hours under $\mathrm{N}_{2}$. After cooling, the resulting $\mathrm{KBr}$ precipitate was removed by vacuum filtration. Removal of solvent from the filtrate in a rotary evaporator under reduced pressure gave $7.30 \mathrm{~g}$ of a yellow oil, which was chromatographed on silica gel and eluted with hexane- $\mathrm{CH}_{2} \mathrm{Cl}_{2}$ ratios of $8: 1,6: 1$, and $4: 1$ to give $1.94 \mathrm{~g}(24 \%)$ of 12-bromododecylthiol acetate as a white solid. Low temperature recrystallization from hexane gave a pure sample: $\mathrm{mp} 39^{\circ} \mathrm{C}$; IR $(\mathrm{KBr}) 1132,1468,1687,2852,2920 \mathrm{~cm}^{-1}$; ${ }^{1} \mathrm{H}$ NMR $(400$ $\left.\mathrm{MHz}, \mathrm{CDCl}_{3}\right) \delta 3.40(\mathrm{t}, 2 \mathrm{H}), 2.85(\mathrm{t}, 2 \mathrm{H}), 2.32(\mathrm{~s}, 3 \mathrm{H}), 1.85(\mathrm{~m}, 2 \mathrm{H}), 1.56(\mathrm{~m}, 2 \mathrm{H})$ 1.57-1.26 (m, $16 \mathrm{H}) ;{ }^{13} \mathrm{C} \mathrm{NMR}\left(400 \mathrm{MHz}, \mathrm{CDCl}_{3}\right), \delta 34.22,33.05,30.8,29.7,29.64,29.61,29.37,29.31$, $29.02,28.96,28.39$.

Synthesis of N-(12-acetylthioldodecyl)-pyridinium bromide. To a solution of $1.96 \mathrm{~g} \mathrm{(24.8}$ mmol) of pyridine in $20 \mathrm{~mL}$ of THF was added $1.42 \mathrm{~g}(4.40 \mathrm{mmol})$ of 12-bromododecylthiol acetate. The solution was heated to reflux for 4 days under a $\mathrm{CaCl}_{2}$ drying column. After cooling to room temperature, the mixture was place in an ice bath. The resulting precipitate of the bromide salt was collected by vacuum filtered and washed with ether $(2 \times 15 \mathrm{~mL})$ and hexane $(15 \mathrm{~mL})$. After drying in a vacuum desicator, $1.53 \mathrm{~g}(81 \%)$ of $\mathrm{N}-(12$-acetylthioldodecyl) pyridinium bromide as a light yellow solid was obtained: $\operatorname{mp} 68^{\circ} \mathrm{C}$; IR $(\mathrm{KBr}) 3046,3021,2919$, 2850, 1688, 1653, 1490, 1127, 1110, 681, 635, $\mathrm{cm}^{-1}$; ${ }^{1} \mathrm{H} \mathrm{NMR}\left(400 \mathrm{MHz}, \mathrm{CDCl}_{3}\right) \delta 9.5(2 \mathrm{H}, \mathrm{d}$, $\mathrm{J}=5.65 \mathrm{~Hz}), 8.52(1 \mathrm{H}, \mathrm{m}), 8.14(2 \mathrm{H}, \mathrm{t}, \mathrm{J}=7.09 \mathrm{~Hz}), 4.96(2 \mathrm{H}, \mathrm{t}, \mathrm{J}=7.41 \mathrm{~Hz}), 2.81(2 \mathrm{H}, \mathrm{t}, \mathrm{J}=$ $7.36 \mathrm{~Hz}), 2.26(3 \mathrm{H}, \mathrm{s}), 2.01(2 \mathrm{H}, \mathrm{m}), 1.51(2 \mathrm{H}, \mathrm{m}),(16 \mathrm{H}, \mathrm{m}) ;{ }^{13} \mathrm{CNMR}\left(100 \mathrm{MH}_{\mathrm{Z}}, \mathrm{CDCl}_{3}\right) \delta$ $196.32,145.40,128.71,62.29,32.20,30.85,29.70,29.53,29.48,29.33,29.23,28.96,26.23$.

Synthesis of N-(12-mercaptododecyl)-pyridinium bromide. A solution of $1.00 \mathrm{~g}$ (2.49 mmol) of N-(12-acetylthioldodecyl)pyridinium bromide in $17 \mathrm{~mL}$ of $1.0 \mathrm{M} \mathrm{HBr}$ (1:1 methanol-water) was heated to reflux under $\mathrm{N}_{2}$ for $24 \mathrm{hr}$. The solvent was removed in a rotary evaporator under reduced pressure leaving a white solid that was recrystallized from $30 \mathrm{ml}$ of deionized $\mathrm{H}_{2} \mathrm{O}$. The crystals were collected by vacuum filtration and dried in a vacuum dessicator. To the filtrate was 
added $2.5 \mathrm{~g}$ of $\mathrm{NaBr}$ resulting in the formation of more crystals that were collected and dried as before giving $\mathrm{N}$-(12-mercaptododecyl)pyridinium bromide in a combined yield of $0.807 \mathrm{~g}$ (71\%): $\operatorname{mp~69-70~}{ }^{\circ} \mathrm{C} ; \mathrm{IR}(\mathrm{KBr}) 3429,3380,3048,2919,2853,1639,1493,1177 \mathrm{~cm}^{-1} ;{ }^{1} \mathrm{H}$ NMR (400 MHz, DMSO) $\delta 9.15(2 \mathrm{H}, \mathrm{d}, \mathrm{J}=6.95 \mathrm{~Hz}), 8.6(1 \mathrm{H}, \mathrm{m}), 8.15(2 \mathrm{H}, \mathrm{t}, \mathrm{J}=6.95), 4.62$ $(\mathrm{m}, 2 \mathrm{H}), 2.44(\mathrm{q}, \mathrm{J}=4.43,2 \mathrm{H}), 2.2(\mathrm{~d}, \mathrm{~J}=7.81,2 \mathrm{H}), 1.87-1.90(\mathrm{~m}, 2 \mathrm{H}), 1.46-1.5(\mathrm{~m} 2 \mathrm{H}), 1.27-$ $1.19(\mathrm{~m}, 20 \mathrm{H}) ;{ }^{3} \mathrm{C}$ NMR $\left(400 \mathrm{MH}_{\mathrm{Z}}\right.$, DMSO) $\delta 146.18,145.41,128.77,61.38,34.01,31.42$, $29.59,29.55,29.44,29.16,29.06,29.40,26.04,24.45$.

\section{Calculation for the possible contact area of the AFM cantilever}

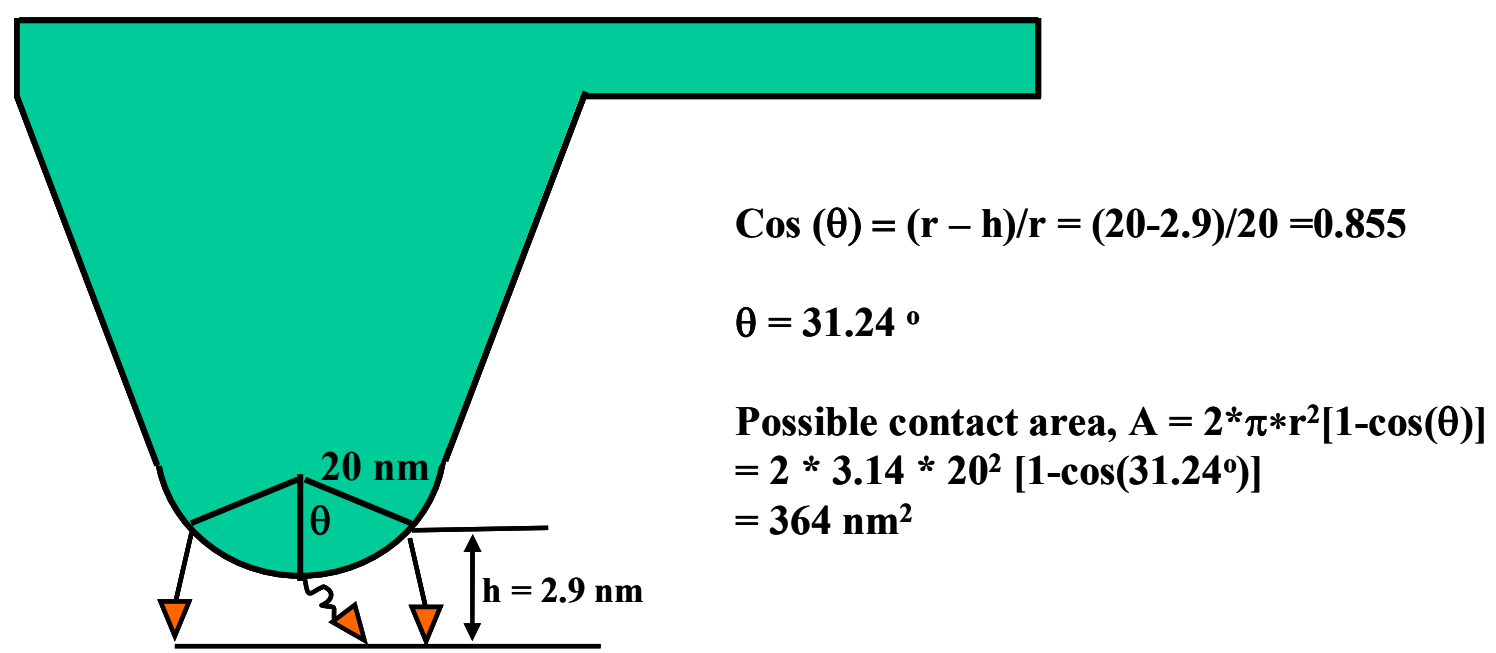

Scheme S2. Calculation for the possible contact area of the AFM cantilever assuming the gold coated AFM tip is spherical with a tip radius of $20 \mathrm{~nm}$.

The flexible linker for (II) is $\sim 2.9 \mathrm{~nm}$ long (excluding the $\mathrm{C}_{11}$ chain which would be rigid when it forms the SAM). Assuming the end of the gold coated AFM tip is spherical with a tip radius of $20 \mathrm{~nm}$, then the possible tip surface area where the sulfonamide inhibitor could come into contact with the enzyme surface (assuming a flat surface) is estimated to be $\sim 360 \mathrm{~nm}^{2}$. This contact area would then contain $\sim 80$ sulfonamide inhibitor molecules (II was diluted with MCU, 1:20), assuming each thiol molecule occupies a surface area of $0.22 \mathrm{~nm}^{2}$. The tip shadow would cover a flat surface of $\sim 330 \mathrm{~nm}^{2}$, within which it would be possible to pack $\sim 25$ carbonic anhydrase molecules if the enzyme is closely packed on the surface (carbonic anhydrase has a diameter of $4 \mathrm{~nm}$ ). These are the theoretical maximum numbers, and in reality the packing density of the enzyme would be smaller. 